\title{
PENGARUH KOMPENSASI, PENEMPATAN KERJA DAN BEBAN KERJA TERHADAP TURNOVER INTENTION KARYAWAN PT. MATAHARI DEPARTEMENT STORE NAGOYA HILL BATAM
}

\author{
Yannik_ariyati ${ }^{1)}$, Andi Mahera ${ }^{2)}$ \\ Prodi Manajemen, Fakultas Ekonomi, Universitas Riau kepulauan \\ Yannik_ariyati@yahoo.co.id ${ }^{1)}$ \\ Prodi Manajemen, Fakultas Ekonomi, Universitas Riau kepulauan \\ andimahera492@yahoo.com ${ }^{2}$
}

\begin{abstract}
ABSTRAK
Pengaruh Kompensasi,Penempatan Kerja dan Beban Kerja Terhadap Turnover Intention Karyawan PT. Matahari Departement Store Nagoya Hill Batam .Penelitian ini bertujuan untuk mengetahui Pengaruh Kompensasi, Penempatan Kerja dan Beban Kerja Terhadap Turnover Intention Karyawan PT. Matahari Departement Store Nagoya Hill Batam. Dan sumber data yang di dapatkan adalah data primer yang di peroleh secara langsung dari jawaban kuesioner karyawan dan karyawati yang bersangkutan dengan penelitian tersebut dengan kualifikasi diatas. Ditambah dengan beberapa referensi dari peneliti sendiri.Berdasarkan hasil penelitian, Kompensasi,Penempatan Kerja dan Beban Kerja Terhadap Turnover Intention Karyawan PT. Matahari Departement Store Nagoya Hill Batam. Berpengaruh signifikan baik secaraparsial, maupun secara simultan pada tingkat kepercayaan 100\%. Nilai $R$ Square pada penelitian ini adalah sebesar 0,331 yang berartihanya 33,1 \% perubahan tingkat Kinerja Karyawan dapat dijelaskan oleh variable Kompensasi,Penempatan Kerja dan Beban Kerja Terhadap Turnover Intention Karyawan PT. Matahari De partement Store Nagoya Hill Batam.Sedangkan sisanya dipengaruhi oleh variabel lain yang tidak teramati dalam penelitian ini.
\end{abstract}

Kata Kunci : Kompensasi,PenempatanKerja,Beban Kerja dan Turnover Intention Karyawan.

\section{PENDAHULUAN}

Manajemen sumber daya manusia merupakan suatu proses untuk menangani berbagai masalah dalam ruang lingkup kerja untuk dapat menunjang aktifitas organisasi atau perusahaan agar mencapai tujuan yang telah ditentukan. Manusia merupakan salah satu unsur yang penting di dalam suatu organisasi, karena manusia merupakan penggerak dan penentu jalannya suatu organisasi. Unsur manajemen sumber daya manusia adalah individu yang merupakan tenaga kerja pada perusahaan. Dengan demikian, fokus yang dipelajari oleh sumber daya manusia adalah masalah yang berpengaruh dengan tenaga kerja manusia.

Salah satu masalah yang berpengaruh dengan tenaga kerja dalam suatu perusahaan adalah tingkat turnover yang tinggi. 
Turnover atau pergantian tenaga kerja merupakan wujud nyata dari turnover intention yang dapat menjadi masalah serius bagi perusahaan atau organisasi, khususnya apabila yang keluar adalah tenaga kerja yang mempunyai keahlian, kemampuan, terampil dan berpengalaman atau tenaga kerja yang menduduki posisi vital dalam perusahaan, sehingga dapat menganggu efektivitas jalannya perusahaan.

PT. Matahari Departement Store Nagoya Hill Batam sangat membutuhkan sumber daya manusia mampu untuk meningkatkan produktivitas perusahaan, karena dengan memiliki tanggung jawab yang tinggi, tujuan yang realitas, rencana kerja yang menyeluruh, berani mengambil resiko yang dihadapai, maka produktivitas perusahaan akan meningkat, oleh karena itu salah satunya adalah dengan meminimalisir turnover intention. Untuk itulah, maka langkah-langkah yang dilakukan untuk mengurangi turnover intention sangat diperlukan.

Adapun Permasalahan yang terjadi tentang masalah kompensasi yang diberikan kepada karyawan, harus memperhatikan lagi tentang perjanjian kerja dari awal, pada awal kontrak kerja sudah jelas tercantum tentang masalah gaji yang diberikan penuh, namun dalam kenyataannya gaji yang diberikan tidak penuh dan bahkan ada juga yang dibawah upah minimum kota batam, dengan kejadian seperti

$\begin{array}{ccc}\text { ini } & \text { akan } & \text { mengurangi } \\ \text { semangat } & \text { kerja } & \text { karyawan. }\end{array}$ Penempatan kerja juga digunakan sebagai tolak ukur seberapa besar produktivitas kerja karyawan tersebut terhadap perusahaan, karena penempatan kerja yang tidak sesuai dengan bidang dan keahlian dapat menimbulkan rasa tidak puas pada diri karyawan dan kurangnya kontribusi kerja karyawan terhadap perusahaan. Beban kerja juga menjadi salah satu penyebab karyawan ingin keluar dari suatu pekerjaan, di PT. Matahari Departement Store beban kerja itu sendiri seperti penambahan waktu atau lamanya waktu kerja dalam perhari dan target penjualan, target penjualan yang telah ditetapkan perusahaan merupakan beban kerja yang harus ditanggung oleh para karyawan . Beban kerja yang dirasa cukup berat dapat berpengaruh pada kondisi fisik dan psikis karyawan.

\section{Tujuanpenelitian}

Berdasarkanlatarbelakangdanrumu sanmasalah yang ada, makapenelitianinidilakukandengantuj uan :

1. Untukmengetahuipengaruhko mpensasiterhadap turnover intention karyawan di PT. MatahariDepartement Store Nagoya Hill Batam.

2. Untukmengetahuipengaruhpe nempatankerjaterhadap turnover intention karyawan di PT. MatahariDepartement Store Nagoya Hill Batam.

3. Untukmengetahuipengaruhbe bankerjaterhadap turnover intention karyawan di PT. MatahariDepartement Store Nagoya Hill Batam .

4. Untukmengetahuipengaruhko mpensasi,penempatankerjada nbebankerjaterhadap turnover intention karyawan di MDS 


\section{Kompensasi}

Kompensasi (balas jasa) langsung merupakan hak bagi karyawan dan menjadikewajibanperusahaan untuk membayarnya. Karena disinilah letak pentingnya kompensasi bagi karyawan sebagai seorang penjual tenaga (fisik dan pikiran).Kompensasi merupakan pengeluaran dan biaya bagi perusahaan, Perusahaan mengharapkan agar kompensasi yang dibayarkan memperoleh imbalan prestasi kerja yang lebih besar dari karyawan.

Menurut Malayu S.P. Hasibuan (2003) menyatakan bahwa: "Kompensasi adalah semua pendapatan yang berbentuk uang, barang langsung atau tidak langsung yang diterima karyawan sebagai imbalan atas jasa yang diberikan kepada perusahaan".

Menurut Siswanto Sastrohadiwiryo (2003) adalah: "Kompensasi adalah imbalan jasa atau balas jasa yang diberikan oleh perusahaan kepada para tenaga kerja karena tenaga kerja tersebut telah memberikan sumbangan tenaga dan pikiran demi kemajuan perusahaan guna mencapai tujuan yang telah ditetapkan".

Menurut T. Hani Handoko (2000) menyatakan bahwa: "Kompensasi adalah segala sesuatu yang diterima oleh karyawan sebagai balas jasa untuk kerja mereka". Adapun pengertian kompensasi menurut Anwar Prabu Mangkunegara (2005) menyatakan bahwa: "Kompensasi merupakan sesuatu yang dipertimbangkan sebagai suatu yang sebanding".

Berdasarkan pendapat para ahli diatas maka dapat diambil kesimpulan bahwa kompensasi merupakan interaksi antara karyawan dengan organisasi, yang berupa timbal balik dari jasa atau tenaga yang dikeluarkan oleh karyawan dan penghargaan dari organisasi dalam bentuk upah atau fasilitas lainnya.

\section{Penempatan Kerja}

Langkah awal dalam menghasilkan sumber daya manusia yang terampil dan andal adalah perlu adanya suatu perencanaan dalam menentukan karyawan yang akan mengisi pekerjaan yang ada dalam perusahaan yang bersangkutan. Keberhasilan dalam pengadaan tenaga kerja terletak pada ketepatan dalam penempatan karyawan, baik penempatan karyawan baru maupun karyawan lama pada posisi jabatan baru. Proses penempatan merupakan suatu proses yang sangat menentukan dalam mendapatkan karyawan yang kompeten yang dibutuhkan perusahaan, karena penempatan yang tepat dalam jabatan yang tepat akan dapat membantu perusahaan dalam mencapai tujuan yang diharapkan.

Menurut Sedarmayanti (2010) menyatakan bahwa penempatan adalah penugasan atau penugasan kembali karyawan pada pekerjaan atau jabatan baru. Sedangkan menurut Tohardi (2002), Penempatan adalah suatu proses mengetahui karakter atau syarat-syarat yang diperlukan untuk mengerjakan suatu pekerjaan (tugas) selanjutnya menjadi orang (Pekerja/pegawai) yang cocok dengan pekerjaan yang ada. Penempatan karyawan menurut Hasibuan (2001) merupakan salah satu kunci untuk memperoleh prestasi kerja yang optimal setiap karyawan, baik kreativitas dan prakarsanya akan berkembang. sedangkan Gomes (2003) menyatakan bahwa penempatan karyawan merupakan salah satu 
fungsi terpenting dalam manajemen sumber daya manusia, tepat tidaknya seseorang ditempatkan pada suatu posisi tertentu tergantung pada fungsi penempatan ini. Jika fungsi ini tidak dilaksanakan dengan baik maka dengan sendirinya akan berakibat fatal terhadap pencapaian tujuantujuan organisasi.

Menurut Fathoni (2006), Prinsip Pokok dalam penempatan pegawai adalah menempatkan orang yang tepat pada tempatnya yang tepat. Menurut Suwatno (2005), penempatan kerja adalah suatu proses pemberian tugas dan pekerjaan kepada tenaga kerja yang lulus seleksi untuk dilaksanakan sesuai ruang lingkup yang telah ditetapkan, serta mampu mempertanggungjawabkansegala risiko dan kemungkinankemungkinan yang terjadi atas tugas dan pekerjaan,

wewenang, serta tanggung jawab.Menurut Hariandja (2005) Penempatan merupakan proses penugasan/pengisian jabatan atau penugasan kembali karyawan pada tugas/ jabatan baru atau jabatan yang berbeda. Sedangkanmenurut Mathis \& Jackson (2006) menyatakan bahwa"Penempatan adalah menempatkan posisi seseeorang ke posisipekerjaan yang tepat, seberapa baik seorang pegawai cocok dengan pekerjaanya akan mempengaruhi jumlah dan kualitas pekerjaan.

Dari pengertian diatas dapat diambil kesimpulan bahwa penempatan karyawan merupakan salah satu usaha untuk menyalurkan kemampuan karyawan sebaikbaiknya dengan jalan menempatkan karyawan pada posisi atau jabatan yang paling sesuai untuk memperoleh prestasi kerja yang optimal. Dengan demikian yang menjadi pokok perhatian utama dalam penempatan karyawan adalah hal-hal yang terdapat dalam diri manusia yang digunakan sebagai dasar dalam menugaskan seseorang pada suatu bidang pekerjaan.

\section{Beban Kerja}

Pengertian beban kerja adalah sekumpulan atau sejumlah keegiatan yang harus diselesaikan oleh suatu unit organisasi atau pemegang jabatan dalam jangka waktu tertentu, Dhania (2010). Menurut Manuaba dan Ambarwati (2014), beban kerja merupakan kemampuan tubuh dalam menerima pekerjaan. Kapasitas pekerjaan harus disesuaikan dengan jumlah karyawan yang ada.

Schultz (2007) menyatakan beban kerja adalah terlalu banyak pekerjaan pada waktu yang tersedia atau melakukan pekerjaan yang terlalu sulit untuk karyawan. Menurut Manuaba (dalam Ambarwati, 2014), beban kerja merupakan kemampuan tubuh dalam menerima pekerjaan. Kapasitas pekerjaan harus disesuaikan dengan jumlah karyawan yang ada. Seperti yang dikatakan oleh Munandar (2008), setiap beban kerja yang diterima seseorang harus sesuai dan seimbang baik terhadap kemampuan fisik, kemampuan kognitif, maupun keterbatasan manusia yang menerima beban tersebut.

Beban kerja karyawan harus disesuaikan dengan kuantitas dimana pekerjaan yang harus dikerjakan terlalu banyak atau sedikit maupun secara kualitas dimana pekerjaaan yang dikerjakan membutuhkan keahlian. Apabila banyaknya tugas tidak sebanding dengan kemampuan baik fisik maupun keahlian dan waktu yang tersedia maka akan menjadi sumber stress, (Ilyas 2009).

Turnover Intention 
Turnover Intention dapat diartikan sebagai pergerakan tenaga kerja keluar dari organisasi. Turnover menurut Robbins dan Judge (2009) adalah tindakan pengunduran diri secara permanen yang dilakukan oleh karyawan baik secara sukarela ataupun tidak secara sukarela. Turnover dapat berupa pengunduran diri, perpindahan keluar unit organisasi, pemberhentian atau kematian anggota organisasi. Culpepper (2011) menyebutkan turnover intention merupakan prediktor terbaik untuk mengindentifikasi perilaku turnover yang akan terjadi pada karyawan suatu organisasi.

Keinginan berpindah kerja (turnover intention) pada karyawan dapat dipengaruhi oleh faktor kepuasan kerja yang dirasakan di tempat kerja (Abdillah, 2012). Satu aspek yang cukup menarik perhatian adalah mendeteksi faktor-faktor motivational yang akan dapat

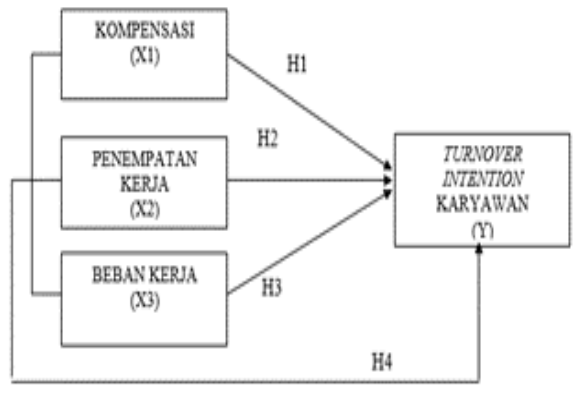

mengurangi niat karyawan untuk meningggalkan organisasi, karena niat buntuk pindah sangat kuat pengaruhnya dalam menjelaskan turnover yang sebenarnya. Adanya karyawan yang keluar dari organisasi memerlukan biaya yang besar dalam bentuk kerugian yang besar akan tenaga ahli, yang mungkin juga memindahkan pengetahuan spesifik perusahaan kepada pesaing (Carmeli dan Weisberg, 2006). Penelitian oleh Suliman dan Al-Junaibi (2010) mengeksplorasi hubungan antara dua komponen komitmen organisasi afektif dan keberlangsungan niat

dan omset antara karyawan yang bekerja di industri minyak. Komitmen organisasi secara keseluruhan terbukti berkorelasi negatif dengan niat omset yang sebangun dengan penelitian sebelumnya. Berkenaan dengan dua komponen komitmen organisasi, kedua komponen tersebut berhubungan negatif dengan keinginan berpindah.

Robbins (2007) menjelaskan bahwa penarikan diri seseorang keluar dari suatu organisasi (turnover) dapat diputuskan secara sukarela (voluntary turnover) maupun secara tidak sukarela (involuntary turnover). Voluntary turnover atau quit merupakan keputusan karyawan untuk meninggalkan organisasi secara sukarela yang disebabkan oleh faktor seberapa manarik pekerjaan yang ada saat ini dan tersedianya alternative pekerjaan lain. Sebaliknya, involuntary turnover atau pemecetan menggambarkan keputusan pemberi kerja (employer) untuk menghentikan hubungan kerja dan bersifat uncontrollable bagi karyawan yang mengalaminya.

\section{Kerangka Pemikiran \\ Hipotesis}

H1 : Diduga Kompetensi berpengaruh terhadap pada kinerja karyawan.

H2 : Diduga Keterlibatan kerja berpengaruh terhadap kinerja karyawan.

H3 : Diduga Kompensasi berpengaruh terhadap kinerja karyawan. 


\section{H4: Diduga \\ Keterlibatan kerja, dan \\ Kompensasi berpengaruh terhadap kinerja karyawan}

\section{METODOLOGI PENELITIAN}

Pada penelitian ini menggunakan teknik pengumpulan data kuisioner (angket). Menurut Sugiyono (2010) “ kuesioner merupakan teknik pengumpulan data dengan cara memberikan pertanyaan atau pernyataan tertulis kepada respondennya untuk menjawab. Teknik pengumpulan data yang dilakukan dalam penelitian ini adalah menggunakan survei kuisioner. Menurut Jogiyanto (2011) survei adalah metode pengumpulan data primer dengan memberikan pertayaan-pertanyaan kepada responden-responden. Adapun jenis data yang digunakan dalam penelitian ini adalah :

\section{Penelitian diskriptif}

Penelitian diskriptif adalah penelitian yang dilakukan untuk mengetahui nilai variable mandiri, baik satu variable atau lebih (independen) tanpa membuat perbandingan, atau menghubungkan dengan variabel yang lain.

\section{Penelitiankomparatif}

Penelitian komparatif adalah suatu penelitian yang bersifat membandingkan. Disini variabel nya masih sama dengan variable mandiri tetapi untuk sampel yang lebih dari satu, atau dalam waktu yang berbeda.

\section{Penelitianasosiatif}

Penelitian asosiatif merupakan penelitian yang bertujuan untuk mengetahui pengaruh ataupun juga hubungan antara dua variable atau lebih. Penelitian ini mempunyai tingkatan tertinggi dibandingkan dengan diskriptif dan komparatif karena dengan penelitian ini dapat dibangun suatu teori yang dapat berfungsi untuk menjelaskan, meramalkan dan mengontrol suatu gejala.

\section{Objek Penelitian}

Adapun yang menjadi objek penelitian ini pada PT. Matahari Departement Store. Tbk yang berlokasi di Komplek Super Block Nagoya Hill, Jl. Teuku Umar

Nagoya, Batam, Riau, yakni sebuah perusahaan yang bergerak di bidang ritel.

\section{Metode Pengumpulan Data}

Metode yang digunakan dalam pengumpulan data-data penelitian ini adalah:
1. Survey
2. Observasi
3. Wawancara
4. Kusioner

Teknik Pengambilan Sampel dan Populasi

Populasi adalah sekumpulan data yang mempunyai karakteristik yang sama dan menjadi sebuah objek. Populasidalam penelitian ini adalah karyawan dan karyawati pada perusahaan PT.MatahariDepartement Store Nagoya Hill Batam yang berjumlah sebanyak 300 orang karyawan.

Sedangkanteknikpengambilansampel pada penelitian inimenggunakanmetodeSystematic random sampling. Denganmenggunakan interval dalammemilihsampelpenelitian.

Menurut Husein Umar mengatakan untuk menentukan berapa minimal sampel yang dibutuhkan jika ukuran populasi diketahui, maka dapat digunakan rumus slovin untuk menentukan jumlah sampelnya seperti berikut :

$\mathrm{n}=\mathrm{N}$ 


$$
1+\mathrm{N} .(\mathrm{e})^{2}
$$

Keterangan :

$$
\begin{array}{ll}
\mathrm{n} & =\text { Jumlahsampel } \\
\mathrm{N} & =\text { Jumlahpopulasi } \\
\mathrm{e} & =\text { Batas toleransi error }
\end{array}
$$

Berdasarkan rumus tersebut, maka jumlah sampel yang diambil didalam penelitian ini adalah :

$$
\begin{array}{ll}
\mathrm{N} & =300 \\
\mathrm{e} & =10 \%(0,1) \\
\mathrm{n}= & \multicolumn{1}{c}{300} \\
\mathrm{n}= & \frac{1+300 \cdot(0,1)^{2}}{300} \\
\mathrm{n}= & \frac{1+300 \cdot(0,01)}{300} \\
\mathrm{n}= & \frac{1+3}{4}
\end{array}
$$

$\mathrm{n}=75$

Jadi, jumlah sampel yang akan diambil dalam penelitian ini adalah 75.

\section{HASIL PENELITIAN DAN PEMBAHASAN \\ Pengujian Alat Pengumpul Data}

Langkah paling penting dalam mengumpulkan data adalah melakukan pengujian terhadap instrumen (alat ukur) yang akan digunakan kegiatan pengujian instrumen penelitian ini meliputi dua hal yaitu pengujian validitas dan reliabilitas.

\section{Uji Validitas}

Uji validitas merupakan suatu langkah pengujian yang harus mengetahui isi dari suatu instrumen (kuesioner), tujuannya adalah untuk mengukur ketepatan instrumen (kuesioner) yang digunakan. Penelitian ini menggunakan teknik korelasi Pearson Product Moment dengan bantuan perangkat lunak SPSS versi 23. Apabila nilai $r$ hasil perhitungan pearson product moment atau $\mathrm{r}$ hitung $>\mathrm{r}$ tabel (untuk $\alpha=$ 0,05 dan derajat kebebasan $(\mathrm{df}=\mathrm{n}-2)$

\begin{tabular}{|c|c|c|c|c|}
\hline Viritible & Ileit & PHllwitin & plibut & Retermpin \\
\hline \multirow{5}{*}{ Ruphesi (XI) } & XI! & 0,0 & 0127 & Villa \\
\hline & X1. & 0,683 & 0127 & Villid \\
\hline & 813 & 0,74 & 027 & Vall \\
\hline & XI. & 0,942 & 00272 & Vilid \\
\hline & $X 15$ & $0,(0)$ & 0,127 & Valid \\
\hline \multirow[t]{4}{*}{ 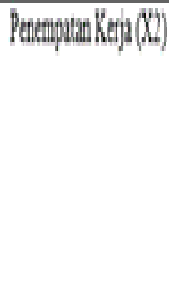 } & Xis & 0,404 & 0127 & Villy \\
\hline & 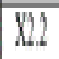 & 0,696 & 0127 & Vilid \\
\hline & Xi? & 069 & 0147 & Vill \\
\hline & X.4 & 0,98 & $0 M$ & Vilid \\
\hline
\end{tabular}

dengan nilai $(0,2441)$ maka

\begin{tabular}{|c|c|c|c|c|}
\hline Wirithe & Iiniti & iflliwi & ithat & Kurringin \\
\hline \multirow{4}{*}{ Btwakeria (X) } & WH & 0,48 & 01727 & Vill \\
\hline & 91 & 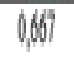 & 0127 & Wall \\
\hline & $M 3$ & 10,14 & 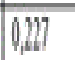 & Vilit \\
\hline & W. & 0130 & 0127 & Wall \\
\hline \multirow[t]{2}{*}{ Thow itation (l) } & VII & 192 & 10217 & Vail \\
\hline & 112 & 094 & 10147 & Vill \\
\hline
\end{tabular}
pernyataan tersebut dinyatakan valid (Sanusi, 2012).

Pengujian ini memiliki 3 variabel bebas yaitu Kompensasi (X1), Penempatan Kerja (X2), Beban Kerja (X3) serta 1 variabel terikat yaitu Turnover Intention Karyawan (Y). Hasil uji masing-masing variabel terhadap item pernyataan akan dirincikan sebagai berikut :

Hasil uji validitas diatas seperti ditampilkan menunjukkan bahwa 
semua butir pernyataan mempunyai nilai $r$ hitung $>r$ tabel, dengan taraf signifikan $\alpha=0,05$ dan nilai $r$ tabel nya sebesar 0,227 dapat disimpulkan bahwa semua pernyataan pada variabel $\mathrm{X} 1, \mathrm{X} 2, \mathrm{X} 3$ dan $\mathrm{Y}$ dinyatakan valid.

\section{Uji Reliabilitas}

Uji Realibilitasdilakukan untuk mendapatkan tingkat ketepatan alat pengumpulan data yang digunakan. Pengukuran realibilitas dilakukan dengan menggunakan SPSS V. 23 uji statistik Cronbrach's Alpha $>0,227$ ( $\mathrm{r}$ tabel)

Berikut hasil uji realibilitas untuk masing- masing variabel :

\begin{tabular}{|c|c|c|c|c|}
\hline Variablel & $\begin{array}{l}\text { Alpha } \\
\text { Croburat }\end{array}$ & $\begin{array}{l}\mathrm{X} O \mathrm{H} \\
\text { Iten } \\
\end{array}$ & t takel & $\mathrm{K}$ \\
\hline Crepensi (XI) & $\sqrt{1}, 27$ & $j$ & 0.227 & Reibitel \\
\hline Peresp & 0,566 & 4 & 02127 & Resiakel \\
\hline tatak & 0,340 & 4 & 0227 & Retiatel \\
\hline invired letrivo & 0,92 & 2 & 0227 & Retike \\
\hline
\end{tabular}

Dari tabel diatas dapat dilihat bahwa $\mathrm{R}$ Alpha dari masing - masing variabel X1, X2, X3 dan $\mathrm{Y}$ lebih besar dari 0,227. Dengan demikian dapat disimpulkan bahwa data yang diuji tersebut dinyatakan reliabel.

Uji Asumsi Klasik

Uji Normalitas

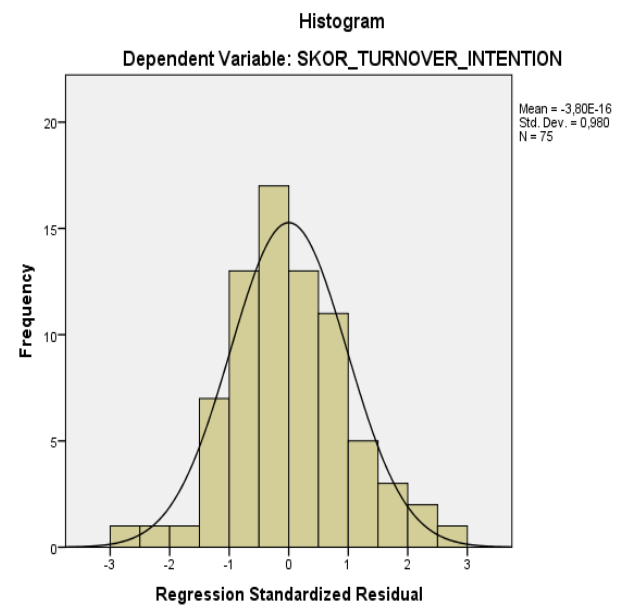

Gambar diatas memperhatikan dan membentuk pola gambar lonceng atau bell shaped maka dapat disimpulkan bahwa data memiliki distribusi normal (Wibowo, 2012). Cara kedua untuk menguji normalitas adalah dengan melihat gambar grafik Normal P-P plot of Regresion Standarized Residual dibawah ini.

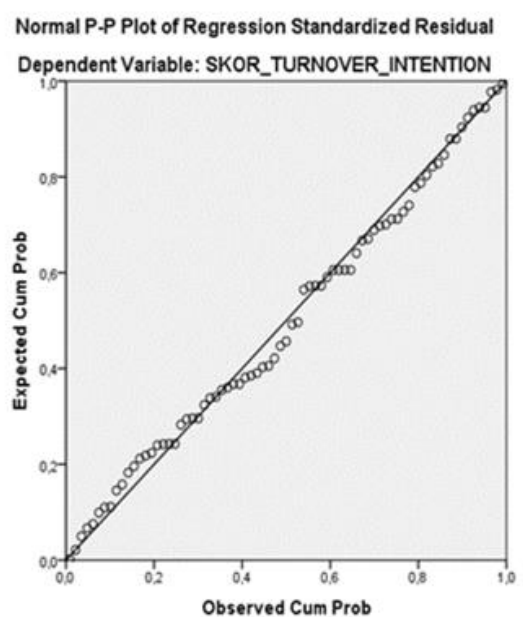

Gambar diatas memperhatikan ketentuan bahwa titik-titik data menyebar disekitar garis diagonal dan mengikuti arah garis diagonal maka dapat dikatakan data memenuhi asumsi normalitas.

\section{Uji Heteroskedastisitas}




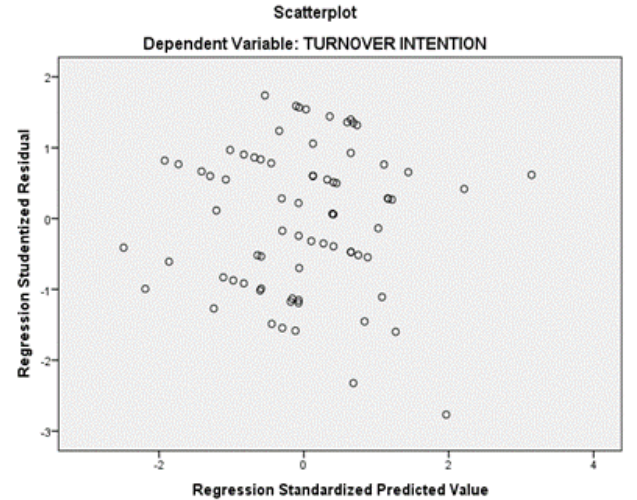

Dan hasil dari pengujian heteroskedastisitas, terlihat titik titik menyebar secara acak dan tidak membentuk sebuah pola tertentu yang jelas dan tersebar baik diatas maupun di bawah angka nol. Maka dapat di simpulkan bahwa tidak terjadi gejala heteroskedatisitas pada data penelitian, sehingga pengujian asumsi klasik dapat di lanjutkan kepada pengujian pengujian berikutnya.

\section{UjiKoefisienDeterminasi $\left(\mathbf{R}^{2}\right)$}

\begin{tabular}{|c|c|c|c|}
\hline Model & $\mathrm{R}$ & RSquare & Adjusted R Square \\
\hline 1 & 5988 & .358 & 331 \\
\hline
\end{tabular}

Hasilperhitungandapatdiketahuibahw akoefisiendeterminasi ( adjusted R2) yang diperolehsebesar 0,331 dantermasukdalamkategoritepat, menunjukkanbahwakontribusivariasi nilai $\quad x 1, \quad x 2, \quad x 3$ dalammempengaruhivariasinilai $\mathrm{Y}$ adalahsebesar $33,1 \%$ sisanya $66,9 \%$ merupakankonstribusivariabel lain yang tidak di ikutsertakan di model penelitianini.

\section{Pengujian Hipotesis}

Uji T (Parsial)

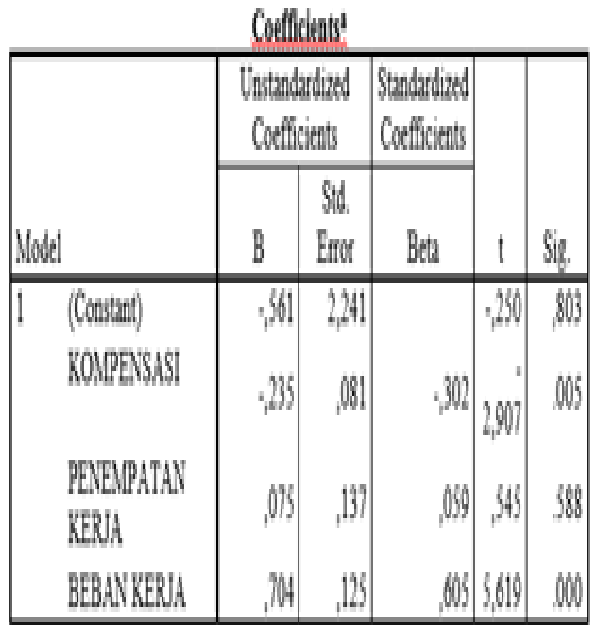

Hasil dari table menunjukkan bahwa variabel kompensasi (X1) nilai $t$ hitung 2,907> t tabel 1,666 dan nilai signifikan $0,005<0,05$ sehingga keputusan yang diambil adalah $\mathrm{H}_{\mathrm{o}}$ ditolak dan $\mathrm{H}_{\mathrm{a}}$ diterima. Hal ini berarti bahwa kompensasi (X1) berpengaruh secara signifikan terhadap turnover intention karyawan.

Variabel penempatan kerja (X2) menunjukkan nilai $t$ hitung $0,545<\mathrm{t}$ tabel 1,666 dan nilai signifikan $0,588<0,05$ sehingga keputusan yang DIAMBIL adalah $\mathrm{H}_{\mathrm{o}}$ ditolak dan $\mathrm{H}_{\mathrm{a}}$ diterima. Hal ini berarti bahwa penempatan kerja tidak berpengaruh secara signifikan terhadap turnover intention karyawan.

Variabel beban kerja (X3) nilai $\mathrm{t}$ hitung 5,619 < t tabel 1,666 dan nilai signifikan $0,000<0,05$ sehingga keputusan yang diambil adalah $\mathrm{H}_{\mathrm{o}}$ ditolak dan $\mathrm{H}_{\mathrm{a}}$ diterima. Hal ini berarti bahwa beban kerja berpengaruh secara signifikan terhadap turnover intention karyawan.

\section{Uji F (Simultan)}




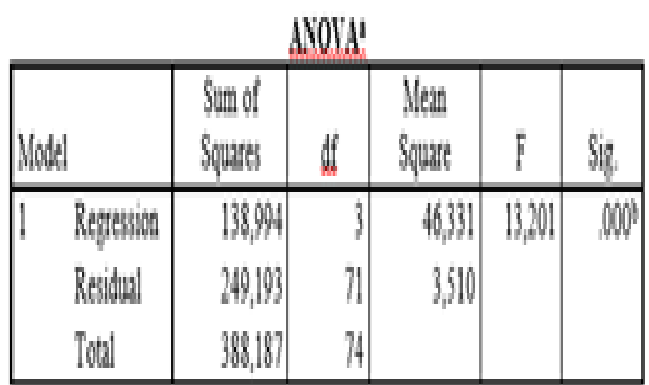

Hasil uji $F$ memperlihatkan nilai $\mathrm{F}$ sebesar 13,201 (F hitung) > 2,73 (F tabel) dan nilai probabilitas signifikansi sebesar $0,000<0,05$ sehingga keputusan yang diambil adalah $\mathrm{H}_{\mathrm{o}}$ ditolak dan $\mathrm{H}_{\mathrm{a}}$ diterima. Hasil ini menunjukkan bahwa variabel kompensasi (X1), penempatan kerja (X2) dan beban kerja (X3) mampu menjelaskan keragaman dari variabel terikat secara bersama-sama terhadap variabel turnover intention karyawan (Y) dan bentuk regresi linear sudah tepat.

\section{Pembahasan}

Bagian ini akan memaparkan pembahasan mengenai hasil analisis yang telah dilakukan, sebagai berikut:

\section{Pengaruh Kompensasi Terhadap Turnover Intention Karyawan}

Berdasarkan hasil pengujian dapat dilihat bahwa kompensasi (X1) dengan nilai koefisien 0,235 berpengaruh secara positif terhadap turnover intention karyawan. Nilai signifikan sebesar $0,005<0,05$ (nilai alpha) menunjukkan adanya hubungan yang signifikan antara kompensasi (X1) dengan turnover intention karyawan (Y). Hal ini diperkuat dengan hasil $t$ hitung 2,907> t tabel 1,666 menunjukkan bahwa variabel kompensasi (X1) berpengaruh secara signifikan terhadap turnover intention karyawan.

\section{Pengaruh Penempatan Kerja Terhadap Turnover Intention Karyawan}

Berdasarkan hasil pengujian dapat dilihat bahwa penempatan kerja (X2) dengan nilai koefisien 0,075 tidak berpengaruh positif terhadap turnover intention karyawan . Nilai signifikan sebesar $0,030>0,05$ (nilai alpha) menunjukkan adanya hubungan yang tidak signifikan antara penempatan kerja (X2) dengan turnover intention karyawan (Y). Hal ini diperkuat dengan hasil $\mathrm{t}$ hitung $0,545<\mathrm{t}$ tabel 1,666 menunjukkan bahwa variabel penempatan kerja (X2) tidak berpengaruh secara signifikan terhadap turnover intention karyawan. Hasil uji variabel penempatan kerja (X2) terhadap turnover intention karyawan(Y).

\section{Pengaruh Beban Kerja Terhadap Turnover Intention Karyawan}

Berdasarkan hasil pengujian dapat dilihat bahwa beban kerja (X3) dengan nilai koefisien 0,704 berpengaruh positif terhadap turnover intention karyawan (Y). Nilai signifikan sebesar $0,000<$ 0,05 (nilai alpha) menunjukkan adanya hubungan yang signifikan antara beban kerja (X3) dengan turnover intention karyawan (Y). Hal ini diperkuat dengan hasil $\mathrm{t}$ hitung $5,619>\mathrm{t}$ tabel 1,666 menunjukkan bahwa variable beban kerja (X3) berpengaruh secara signifikan terhadap turnover intention karyawan. Hasil uji variable beban kerja (X3) terhadap turnover intention karyawan (Y).
4. Pengaruh
Kompensasi, Penempatan Kerja dan Beban 


\section{Kerja Terhadap Turnover Intention Karyawan}

Hasil uji $F$ menunjukkan bahwa nilai signifikan dari 3 variabel bebas yaitu variabel kompensasi (X1), penempatan kerja (X2) dan beban kerja (X3) sebesar 0,000 dan F hitung 13,201. Hasil ini memperlihatkan bahwa variabel kompensasi (X1), penempatan kerja (X2) dan beban kerja (X3) secara bersama-sama memiliki pengaruh yang signifikan terhadap turnover intention karyawan (Y).

\section{KESIMPULAN}

Berdasarkan hasil analisis dan pembahasan yang telah dilakukan pada bab-bab sebelumnya, maka hasil penelitian ini dapat disimpulkan sebagai berikut:

1. HasilUji t untuk variable kompensasi (X1) di peroleh nilai t hitung $>\mathrm{t}$ tabel $(2,907>1,666)$ dansignifikan $<0,05(0,000<0,05$ ) maka $\mathrm{H} 0$ ditolakdan $\mathrm{H} 1 \mathrm{di}$ terima, artinya kompensasi (X1) berpengaruh secara signifikan terhadap variabel turnover intention ( $\mathrm{Y}$ ).

2. HasilUji $t$ variable penempatan kerja (X2) di perolehnilai $t_{\text {hitung }}<\mathrm{t}$ tabel $(0,545<1,666 \quad)$ dan signifikan>0,05 $(0,030>0,05)$ maka $\mathrm{H} 0$ diterimadan $\mathrm{H} 1$ ditolak, artinya penempatan (X2) tidak berpengaruh secara signifikan terhadap turnover intention (Y).

3. Hasil Uji $t$ variable beban kerja (X3) di peroleh bahwa nilai $t$ hitung $>t$ tabel $(5,619>1,666)$ dansignifikan $<0,05(0,000<0,05$ )

maka $\mathrm{H} 0$ ditolakdan $\mathrm{H} 1$ diterima, artinyabebankerja

berpengaruh secara signifikan terhadap turnover intention (Y).

4. Dari Hasil uji $F$ memperlihatkan nilai $\mathrm{f}$ hitung $=13,201>2,73(\mathrm{f}$ tabel ) dengan signifikasi sebesar $0,000<0,05$. Yang berarti $\mathrm{Ha}$ diterima dan $\mathrm{HO}$ di tolak, hal ini berarti bahwa secara bersama sama atau simultan kompensasi, penempatan dan beban kerja mempunyai pengaruh yang positif dan signifikan terhadap turnover intention (Y). Karyawan PT. MatahariDepartement Store Nagoya Hill Batam.

\section{SARAN}

Berdasarkan kesimpulan yang telah dilakukan maka saran yang dapat diberikan dalam penelitian ini yaitu:

1. Diharapkan kepada pihak perusahaan dapat mempertahankan serta meningkatkan sistem kompensasi, perusahaan harus mempertahankan sistem kompensasi tanpa diskriminasi dalam hal apapun. Hal tersebutlah yang dapat menciptakan kepuasan dan komitmen kerja melalui kompensasi sehingga turnover intention akan menurun.

2. Diharapkan kepada pihak perusahaan pada proses penempatan kerja untuk lebih mempertimbangkan kesesuaian posisi atau jabatan karyawan. Posisi atau jabatan yang disesuaikan dengan keahlian atau keterampilan yang dimiliki karyawan, akan membuat karyawan bekerja dengan sepenuh hati, sebaliknya ketika karyawan merasa tidak senang mereka akan merasa seperti bekerja di bawah tekanan.

3. Diharapkan kepada pihak perusahaan harus lebih memperhatikan lagi beban kerja yang dirasakan karyawan karena beban kerja merupakan 
salah satu faktor yang dapat menjadi pertimbangan bagi karyawan untuk tetap menetap atau meninggalkan perusahaan.

4. BagiPenelitiSelanjutnya, penelitian ini dapat dijadikan referensi dan disarankan untuk mengembangkan ruang lingkup penelitian agar dapat memberikan gambaran yang lebih luas mengenai faktorfaktor yang mempengaruhi turnover intention karyawan.

\section{DAFTAR PUSTAKA}

Abdillah, Teguh Sulistiyani, dan Rosidah. 2012. Manajemen Sumber Daya Manusia.Yogyakarta: Graha Ilmu.

Cain, B. (2007). A Review of The Mental Workload Literature.

Defence Research and Development Canada Toronto. Human System Integration Section : Canada

Cao, Z., Chen J., and Song, Y. 2008. Does total rewards reduce the core employees' urnover intention?. International Journal of Business and Management. 20(8), pp: 62-75.

Fathoni, Abdurrahmat. 2006. Manajemen Sumber Daya Manusia. Jakarta: PT Rineka Cipta.

Gomes, Faustino Cardoso. 2003.

Manajemen Sumber Daya Manusia. Yogyakarta: Penerbit Andi.

Hasibuan, S. P Malayu. 2003. Manajemen Sumber Daya Manusia. Jakarta: Bumi Aksara.

Hariandja. 2005. Effect of Job Satisfaction on Managerial Performance in Bank
Nagari Padang Headquarters.

Business Management

Dynamics,(1): pp: 66-84.

Harnoto,Tohardi.Hani. (2002).

Manajemen Personalia dan Sumber Daya Manusia.Edisi 2. Yogyakarta: BPFE

Mangkunegara, A.A Anwar Prabu. 2005. Manajemen Sumber Daya ManusiaPerusahaan. Bandung: Remaja Rosdakarya.

Mathieu, J.E. and Zajac, D.M. (2000), "A review and metaanalysis of the antecedents, correlates, and consequences of organizational commitment", Psychological Bulletin, Vol. 108 No. 2, pp. 171-20.

Manuaba, Ambarawati, Ashar Sunyoto. 2014. Cetakan Ke 1

Psikologi Industri Dan

Organisasi. Universitas

Indonesia, Jakarta.

Novliadi, A Raymond, Dkk. 2007. Manajemen Sumber Daya Manusia Buku 2 Edisi Jakarta: Salemba Empat.

Panggabean, S., Mutiara. 2004. Manajemen Sumber Daya Manusia. Bogor: Ghalia Indonesia

Robbins, Stephen P, 2007, Perilaku Organisasi, Buku I, Edisi Indonesia. Jakarta :PT.Indeks

Robbins, S. P., Judge, T. A. (2009). Perilaku Organisasi. Edisi 12 buku 1Jakarta: Salemba Empat.

Rivai, H. Veithzal dan Sagala, Ella Jauvani. 2004. Manajemen Sumber Daya Manusia Untuk Perusahaan. Edisi 2. Jakarta : PT. Raja Grafindo.

Rachmawati, Ike Kusdyah. 2007. Manajemen Sumber Daya Manusia.Yogyakarta: 
Sudarmanto. 2009. Kinerja dan Pengembangan SDM. Jakarta: Pustaka Pelajar.

Sedarmayanti. (2010). Manajemen Sumber Daya Manusia. Edisi 1. Bandung: RefikaAditama.

Sastrohadiwiryo, B. Siswanto.(2005). Manajemen Tenaga Kerja Indonesia Pendekatan Administratif dan Operasional. Jakarta: Bumi Aksara

Sekaran, U. (2006). Metodelogi Penelitian Untuk Bisnis. Edisi 4. Jakarta: SalembaEmpat.

Staffelbach, B. (2008). Turnover Intent. Diploma Thesis. University of Zurich, Swiss.

Tarwaka, A. (2015). Analisis Beban Kerja Ditinjau Dari Faktor Usia Dengan Pendekatan

Widjaja, D. C. (2012). Analisis Persepi Employee Empowerment Terhadap Employee Turnover Intention Di Hotel X, Kupang, Nusa Tenggara. Jurnal Management Perhotelan.

Wahyudi, A. 2008. Membangun Komitmen Organisasional Untuk Meningkatkan Kinerja dan Daya Sasing Organisasi. Joglo, 20(1). 